\title{
Dorper sheep utilizing feed resources efficiently: a Mediterranean case study
}

\author{
Sezen Ocak ${ }^{1}$, Sinan Ogun², Onur Yilmaz ${ }^{3}$ \\ ${ }^{1}$ Nigde University, Faculty of Agricultural Sciences and Technologies, Department of Animal Production and Technologies, Nigde, Turkey. \\ ${ }^{2}$ Red Rock Agricultural Pastoral Research, Ankara, Turkey. \\ ${ }^{3}$ Adnan Menderes University, Faculty of Agriculture, Department of Animal Science, Aydin, Turkey.
}

\begin{abstract}
The aim of the study was to determine the effect varying feeding systems would have on meat quality and production. The study looked at 45 Dorper lambs which were subjected to three different feeding protocols representing three alternate production systems: extensive grazing system (Group G), an intensive feedlot system being fed concentrate + alfalfa hay (Group C), and a semi-intensive production system comprising grazing + concentrate (Group GC). The lambs were slaughtered 62 days after weaning at approximately four months of age and meat quality factors such as $\mathrm{pH}$, colour, shear force, cooking and water loss, as well as carcass characteristics; back fat thickness, muscle depth, muscle width, and muscle area were measured instrumentally on the longissimus dorsi muscle. A new measuring index was used to assess feed cost against weight gain to determine performance for profitability. In calculating cost $\mathrm{kg}^{-1}$ live weight gain, the extensive grass-fed production was significantly lower, approximately $70 \%$ less than the intensive feedlot system. Very little significant effect on meat quality was seen among the three systems. Slaughter weight had a significant effect on hot carcass weight, cold carcass weight, and drip loss. The lean carcass trait of the Dorper breed was a major positive attribute, but minor benefits gained in meat quality with the feedlot production system did not justify the substantial additional cost of production. Dorper sheep can be considered efficient feed converters on pasture, and thus a suitable breed for lamb meat production in countries like Turkey, where feed costs are the main contributor to farm outgoing.
\end{abstract}

Key Words: feed conversion, feed expense efficiency, meat quality, productivity

\section{Introduction}

Climate and geographical conditions are major determinants for the type of animal production system a producer will embark on, while production cost remains the main element for the success of that system. Sheep are suited to a variety of farming operations due to their nutritional versatility and adaptability. They can be fed a very high-concentrate diet or a solely forage diet, or any combination of both with acceptable results (Guerin et al., 1988; Dicko and Sikena, 1991; Cissé et al., 2002). Much scientific research has been carried out on quantitative and qualitative intake of pen-fed livestock (Schwartz and Schafft, 1988); however, similar quality data for grazing livestock have been disappointingly lacking or unreliable (Dicko and Sikena, 1991), in particular for the Mediterranean region, where extensive production is widely utilized. Because small ruminants are normally fed ad libitum, voluntary

Received January 19, 2016 and accepted June 8, 2016.

Corresponding author: sezenocak1@gmail.com

http://dx.doi.org/10.1590/S1806-92902016000800010

Copyright (C) 2016 Sociedade Brasileira de Zootecnia. This is an Open Access article distributed under the terms of the Creative Commons Attribution License (http://creativecommons.org/licenses/by/4.0/), which permits unrestricted use, distribution, and reproduction in any medium, provided the original work is properly cited. feed intake is crucial in feeding tactics and strategies aimed at optimal animal production. Such information can be employed to develop a keener nutritional knowledge for improving productivity of small ruminant production in the region and afar where similar conditions prevail. It is generally accepted by Mediterranean sheep producers that grass is the most economical feed during the grazing season whether the pasture is improved or not. Using this as a premise and accepting the fact that there is limited scientific evidence available to ascertain true grazing optimization by small ruminants due to uncertainties with in vivo digestibility and voluntary intake, the authors in this study have made a number of informed suppositions with regard to the sampling of the grazing group of lambs; these are examined in the discussion section. There are numerous ways to express levels of grazing intake by small ruminants. Regarding the estimation of feed intake for grazing sheep, the accuracy of estimates based on empirical models developed so far is very low when applied out of the boundaries of the studied system. Feeding experiments indoors and outdoors remain fundamental for a better modelling and understanding of the interactions between feeds and small ruminants (Pulina et al., 2013). Commonly, the intake of forage dry or organic matter (DM or OM) is expressed in weight unit per animal and per day, but the 
expression cannot be used to compare animal species or forages. Therefore, intake may be expressed by kilograms of body weight raised to an exponent that can vary between 0.54 and 1.00 (Meissner and Paulsmeier, 1995). The choice of the exponent is a function of forage quality. With low quality forage, the intake capacity of the animal appears more linked to the gut fill capacity and to the forage passage rate. For such forages, the exponent is 1.00 and intake is expressed per $\mathrm{kg}$ of body weight or in per cent of body weight (Demment and Van Soest, 1985). Intake of good quality forages seems more controlled by physiological mechanisms. Intake of such forages is usually expressed per $\mathrm{kg}$ of metabolic weight (body weight raised to 0.75 ). The assumption is that intake is linked to energy requirements that are proportional to 0.75 power of body weight (Allison, 1985). In their study, Sauvant et al. (2006) showed that, to compare intake levels across forages and animal species, the best unit remains the dry matter in per cent of body weight (DMI, \% BW). On this basis, relations between intake and passage rate of particles through the rumen or the energy digestibility appear independent of animal species (Decruyenaere et al., 2009).

Most sheep farms in the Mediterranean region spring lambing programs use the natural breeding cycle of the ewe, which improves breeding efficiency and potential pasture utilization. Sheep breeds in Turkey are mainly fat tailed, multi-purpose, and have low productivity raised under extensive conditions relying on pasture utilization (Gursoy, 2006). Sheep farming in Turkey has historically utilized its lamb and mutton production in a similar manner, sustaining itself through the use of natural grassland and meadows under extensive grazing conditions. The majority of these farms complete their fattening process typically after the lambs have reached five months of age. Sheep production has a very important role in meeting the red meat market demand in Turkey. In contrast to the Mediterranean countries of the EU where light lamb consumption is preferred, the typical lamb meat consumption in Turkey is based on hogget production (1year-old; 40-50 kg live weight) usually fattened in feedlot conditions with ad libitum barley until slaughter. Only a minority of consumers in Aegean and Marmara regions of Turkey prefer lighter lambs at around $15-17 \mathrm{~kg}$ carcass weight. However, due to the genetic characteristics of the local breeds, the deposition of fat at this age intensifies more on the surface of the carcass than in the muscle tissue. High subcutaneous fat resulting in a lower carcass yield is obviously not a preferred trait, as it is removed prior to the final price assessment of the carcass. Since Turkey at present has no set carcass quality standards in place, the producer is only driven by the productivity aspect of their livestock production and needs to be directed toward better use of fodder resources in order to save on worthless fat production. Lamb producers often believe net returns are directly related to higher production rates; however, lowering production costs has shown to be a more realistic means to increase net profit from their sheep enterprise. This can be done for instance by increasing productivity through lowering feed costs. As feed costs are usually the largest expense associated with raising sheep or fattening lambs, improving feed conversion rates or other efficiencies in the fodder cycle is arguably the most sensible productivity tool. In intensive production systems, proximity to areas where feed is produced, imported or processed, presents advantages in terms of reducing the cost of inputs, of which feed typically accounts for approximately 70\% (Ocak et al., 2007).

Changes in production systems aimed at increasing animal productivity and economic results are desirable, provided meat quality and consumer acceptance are maintained (Santos-Silva et al., 2002). Lamb carcass and meat quality may vary according to the husbandry system (Chestnutt, 1994) and the main traits taken into account by consumers are fat and meat colour. Moreover, lamb carcass characteristics (yield, fat content, fat colour, etc.) and meat quality parameters $(\mathrm{pH}$, colour, water holding capacity, and toughness) might change as a result of the feeding system (Priolo et al., 2002; Joy et al., 2008). Given this context, fat and meat colour have a great influence on the acceptability to consumers (Carpenter, 1966); therefore, it is crucial to assess the effect of production/feeding system on these traits.

In this study, authors aimed to assess the effect of different feed regimes on efficiencies of cost, carcass characteristics, and meat quality of Dorper lambs to ascertain whether recommendations could be made for improving production system profitability.

\section{Material and Methods}

The experiment was carried out in Gaziantep, Turkey, during the summer season. The location of the site is $37^{\circ} 02^{\prime} 26^{\prime \prime} \mathrm{N}$ and $37^{\circ} 18^{\prime} 25^{\prime \prime} \mathrm{E}$, with an altitude of $860 \mathrm{~m}$. Steppic habitats represent the major natural vegetation in the region. Much of the steppes are dominated by xerophytic species as the area is semi-arid with vast natural grazing lands suitable mainly for small ruminant production. Gaziantep region where the experiment was carried out has a Mediterranean type climate with influences of continental climate during winter; i.e., hot, dry summers (minimum $15{ }^{\circ} \mathrm{C}$; maximum $38^{\circ} \mathrm{C}$ ) and cool, wet, occasionally snowy 
winters (minimum $-1{ }^{\circ} \mathrm{C}$; maximum $13{ }^{\circ} \mathrm{C}$ ) with average annual precipitation and humidity of $560 \mathrm{~mm}$ and $57 \%$, respectively. The typical breeds used in the area for lamb production are Awassi and Akkaraman.

All experimental procedures were approved by the Ethical Committee of Zirve University, Gaziantep, Turkey, ensuring compliance with EC Directive 86/609/EEC for animal experiments.

The experimental animals were a flock of 45 mixed white and black Dorper intact male lambs weaned at 50 days of age to begin the study, housed in three separate semi-open pens (15 lambs in each group). The three differing feeding protocols used were grazing only (Group $\mathrm{G}$ - extensive production system), grazing with some supplementary concentrate (Group GC - semi-extensive production system), and only concentrate feed with ad libitum alfalfa hay (Group C - intensive feedlot production). The first group (G) of lambs grazed ad libitum on 5 ha of dryland mix pasture consisting of lucerne (Medicago sativa, 6\%) perennial ryegrass (Lolium perenne multiflorum, $20 \%$ ), cocksfoot (Dactylis glomerata, 10\%), smooth brome (Bromus inermis, 10\%), common sainfoin (Onobrychis sativa, 6\%), vetch (Vicia sativa, 9\%), white and red clover (Trifolium sp, 9\%), and 30\% native species. The extensive production Grazing (G) group was not provided with any other supplementary feed until slaughter. In grazing, the ad libitum intake of a reference grass ( $15 \%$ of crude protein, $77 \%$ of organic matter digestibility on a dry matter basis) is $75 \mathrm{~g}$ of dry matter per $\mathrm{kg}$ of metabolic weight for a standard sheep (INRA, 2007). For the net margin calculations, all pasture establishment associated costs, including irrigation, fertilizer application, energy costs, labour etc., were taken into account. Although this pasture trial could be considered not to have true a replication, the above supposition of the grazing intake assessment is often used reliably by graziers. In the second semi-extensive, grazing + concentrate (GC) group, the same pasture improved paddock was also grazed for $2 \mathrm{~h}$ each day and the group also received an additional $300 \mathrm{~g}$ of concentrate feed per lamb per day (as detailed below) until slaughter. The third, intensive concentrate feed only (C) group of lambs was kept in the feedlot all day and given a restricted diet consisting of (average) 500 g lamb ${ }^{-1}$ day $^{-1}$ concentrate pellets and $300 \mathrm{~g} \mathrm{lamb}^{-1}$ day $^{-1}$ alfalfa hay until slaughter. Any excess feed left in the pens at the end of the day was measured, recorded, and taken into consideration when calculating final feed intake before being discarded. The ingredients and composition of concentrate pellet feed were as follows: $25 \%$ chickpeas, $12 \%$ lentils, $20 \%$ corn, $20 \%$ barley, $10 \%$ wheat, $10 \%$ bran, and $3 \%$ salt and minerals.
All the lambs were weaned at 50 days of age, weighed, recorded, and placed into their respective pens. They were given a 10-day period of adjustment to their respective feed protocols before commencing the experimental data collection. During this transition period, their feed intake was recorded and monitored but not used in the analysis. The experiment lasted an additional 62 days until the lambs were sent to a local registered slaughterhouse for the relevant sample assessment. Samples from 15 lambs from each group (i.e., 45 lambs total) were used for the meat quality and carcass characteristic assessment. The data from the total 45 lambs were used for the average daily gain (ADG) and feed cost efficiency assessments. ADG was calculated as the amount of weight gained per day for the animal gained over the given period (62 days). During the study, the animals were weighed weekly using a digital scale and the total weight gain was calculated and divided by the experiment duration (62 days) to calculate average daily gain (ADG), while feed conversion rate (FCR) was calculated by dividing total feed intake by ADG. Costing for each feeding regime was calculated based on farm running cost figures. Only operating costs were taken into consideration as variables, i.e., labour, energy, administration, veterinary, and ancillary costs. Fixed farm costs were not taken into consideration when making the comparison between the feed costs of production systems. The calculated amounts for these feed costs were similar to the national average for Turkey and the currency used is US dollars. The authors used a new parameter, feed expense efficiency (FEE), to express the cost of feed to gain $1 \mathrm{~kg}$ of live weight. This was calculated by initially estimating the average daily feed cost $\left(\mathrm{FE}_{\mathrm{pd}}\right)$ and then multiplying it by 1000/ADG (g).

The lambs were slaughtered in a licensed abattoir. The carcasses were processed according to the Standard Mediterranean Method described by Colomer-Rocher et al. (1987). At slaughter, head, skin, feet, and offal were removed and hot carcass weight was recorded. The carcass was split down the dorsal midline and the left side was used for measurements. The left side was then divided into the five standard cuts neck, shoulder, long leg, ribs, and flank, as described by Colomer-Rocher et al. (1987). The section taken from the 12th and 13th rib area of the longissimus dorsi muscle (LD) was drawn on parchment paper and backfat thickness (BF), muscle depth (MD), muscle width (MW), and muscle area (MA), were measured with a planimeter (USHIKATA X-PLAN 380 DIII, Japan). This was performed on the total 45 lambs.

The $\mathrm{pH}$ on longissimus dorsi muscle (LD) was measured 45 min after slaughter $\left(\mathrm{pH}_{45}\right)$ and $24 \mathrm{~h}$ post- 
slaughter $\left(\mathrm{pH}_{24}\right)$ using a Jenway $\mathrm{pH}$ meter (Jenway 3010; Jenway LTD, Essex, UK) equipped with an electrode (J95, 924001; Jenway LTD, Essex, UK).

Colour measurements of muscle surfaces $-L^{*}$ (lightness), $\mathrm{a}^{*}$ (redness), and $\mathrm{b}^{*}$ (yellowness) - were made using a HunterLab ColorFlex (A60-1010-615 Model Colorimeter, Hunter Lab, Reston, VA). The instrument was standardized with a white and black ceramic plate $\left(\mathrm{L}^{*}=\right.$ 93.01, $\mathrm{a}^{*}=-1.11$, and $\left.\mathrm{b}^{*}=1.30\right)$. The colour co-ordinates $\left(\mathrm{L}^{*}, \mathrm{a}^{*}\right.$, and $\left.\mathrm{b}^{*}\right)$ were measured three times on the muscle surface averaged for statistical analyses. Instrumental meat quality characteristics investigated in the current study were water loss (WL, \%), cooking loss (CL, \%), and Warner Bratzler shear force $\left(\mathrm{SF}, \mathrm{kg} / \mathrm{cm}^{2}\right)$, and were measured in the longissimus dorsi muscle samples. Cooking loss (\%) and water loss (\%) were performed as described by Hoffman et al. (2003). Shear force values were obtained using a Zwik/Roell texture analysis test device equipped with a V-shaped knife of a Warner Bratzler shear force apparatus.

The UNIVARIATE procedure of SAS (Statistical Analysis Sytstem, version 8.0) statistical package program was used to check normality of the data. The result of this analysis showed that the data for all the measured characteristics were distributed normally. Afterwards, GLM and CORR procedures were used for analysis of variance, least squares means, and phenotypic correlation coefficients. The GLM is an ANOVA procedure in which the calculations are performed using a least squares means approach to describe the statistical relationship between one or more predictors and a continuous response variable. Predictors can be factors and covariates. Duncan's test was used to carry out the comparative analysis.

Mathematical models used in statistical analysis are given below:

Model for ADG, feed intake, including grazing and cost per $1 \mathrm{~kg}$ of LW gain:

$$
Y_{i j}=\mu+\alpha_{i}+b_{1}\left(X_{i j}-\bar{X}\right)+e_{i j},
$$

in which $Y_{i j}=$ observation of feed efficiency; $\mu$ = overall mean of the trait; $\alpha_{\mathrm{i}}=$ fixed effect of production system ( $i=$ grazing, grazing + concentrate, and concentrate + alfalfa hay); $b_{1}=$ regression coefficient of slaughter weight; $\overline{\mathrm{X}}=$ mean slaughter weight of animals; $\mathrm{X}=$ slaughter weight of animals; and $\mathrm{e}_{\mathrm{ij}}=$ random errors with the assumption of $\mathrm{N}$ $\left(0, \sigma^{2}\right)$

Formula for feed expense efficiency:

$$
F E E=F E_{p d} x \frac{1000(g / L W)}{A D G(g)},
$$

in which $\mathrm{FEE}=$ feed expense efficiency; $\mathrm{FE}_{\mathrm{pd}}=$ feed expense per day; $\mathrm{LW}=$ live weight; and $\mathrm{ADG}=$ average daily gain.
Models for carcass characteristics:

Model for hot carcass weight, cold carcass weight, dressing percentage, and drip loss:

$$
\mathrm{Y}_{\mathrm{ij}}=\mu+\alpha_{i}+\mathrm{b}_{1}\left(\mathrm{X}_{\mathrm{ij}}-\overline{\mathrm{X}}\right)+\mathrm{e}_{\mathrm{ij}}
$$

Model for slaughter weight and average daily gain:

Model for initial weight:

$$
\mathrm{Y}_{\mathrm{ij}}=\mu+\alpha_{i}+\mathrm{b}_{2}\left(\mathrm{~A}_{\mathrm{ij}}-\overline{\mathrm{A}}\right)+\mathrm{e}_{\mathrm{ij}}
$$

$$
\mathrm{Y}_{\mathrm{ij}}=\mu+\alpha_{i}+\mathrm{e}_{\mathrm{ij}},
$$

in which $\mathrm{Y}_{\mathrm{ij}}=$ observation of carcass characteristics; $\mu=$ overall mean of the trait; $\alpha_{i}=$ fixed effect of production system $(i=$ grazing, grazing + concentrate, and concentrate + alfalfa hay); $b_{1}=$ regression coefficient of slaughter weight; $\mathrm{b}_{2}=$ regression coefficient of initial weight; $\overline{\mathrm{X}}=$ mean slaughter weight of animals; $X_{\mathrm{ij}}=$ slaughter weight of animals; $\mathrm{A}_{\mathrm{ij}}=$ initial weight of animals; $\overline{\mathrm{A}}=$ mean initial weight of animals; and $\mathrm{e}_{\mathrm{ij}}=$ random errors with the assumption of $\mathrm{N}$ $\left(0, \sigma^{2}\right)$.

Models for MLD and carcass components:

$$
\mathrm{Y}_{\mathrm{ij}}=\mu+\mathrm{a}_{\mathrm{i}}+\mathrm{b}\left(\mathrm{X}_{\mathrm{ij}}-\overline{\mathrm{X}}\right)+\mathrm{e}_{\mathrm{ij}} \text {, }
$$

in which $Y_{i j}=$ observation of MLD and carcass components; $\mu=$ overall mean of the trait; $a_{i}=$ fixed effect of production system $(i=$ grazing, grazing + concentrate, and concentrate + alfalfa hay); $b=$ regression coefficient of cold carcass weight; $\overline{\mathrm{X}}=$ mean cold carcass weight of animals; $\mathrm{X}_{\mathrm{ij}}=$ carcass weight of animals; and $\mathrm{e}_{\mathrm{ij}}=$ random errors with the assumption of $\mathrm{N}\left(0, \sigma^{2}\right)$.

Models for $\mathrm{pH}$ and colour characteristics:

$$
\mathrm{Y}_{\mathrm{ij}}=\mu+\alpha_{\mathrm{i}}+\mathrm{e}_{\mathrm{ij}} \text {, }
$$

in which $\mathrm{Y}_{\mathrm{ij}}=$ observation of $\mathrm{pH}$ and colour characteristics; $\mu=$ overall mean of the trait; $\alpha_{i}=$ fixed effect of production system $(i=$ grazing, grazing + concentrate, and concentrate + alfalfa hay); and $\mathrm{e}_{\mathrm{ij}}=$ random errors with the assumption of $\mathrm{N}\left(0, \sigma^{2}\right)$.

Models for meat characteristics:

$$
\mathrm{Y}_{\mathrm{ij}}=\mu+\alpha_{\mathrm{i}}+\mathrm{e}_{\mathrm{ij}} \text {, }
$$

in which $Y_{i j}=$ observation of meat characteristics, $\mu=$ overall mean of the trait, $\alpha_{\mathrm{i}}=$ fixed effect of production system $(i=$ grazing, grazing + concentrate, and concentrate + alfalfa hay); and $\mathrm{e}_{\mathrm{ij}}=$ random errors with the assumption of $\mathrm{N}\left(0, \sigma^{2}\right)$.

\section{Results}

The lambs were slaughtered at 122 days of age, following a 62-day experiment period. Whilst the initial weights of all lambs were similar (mean $22.10 \mathrm{~kg}$; Table 1), C group lambs had the heaviest slaughter weights (mean $34.28 \mathrm{~kg} \pm 1.15$ ), followed by the GC group (mean $32.10 \mathrm{~kg} \pm 1.16$ ) and the lightest being the $\mathrm{G}$ group (mean $30.31 \mathrm{~kg} \pm 1.16$ ), making their average daily weight gains $161 \mathrm{~g}, 143 \mathrm{~g}$, and $116 \mathrm{~g}$, 
respectively (Table 1). The coefficient for regression of initial weight (IW) on slaughter weight (SW) was highly significant $(\mathrm{P}<0.01)$, and less significant $(\mathrm{P}<0.05)$ on average daily gain (ADG). The grazing group $(\mathrm{G})$ cost was calculated at $\$ 0.07$ animal $^{-1}$ day $^{-1}$, while group GC feed cost was found to be $\$ 0.13$ animal $^{-1}$ day $^{-1}$ and group $C$ was $\$ 0.30$ animal $^{-1}$ day $^{-1}$. The feed expense efficiency (FEE) parameter for calculating the cost for each kilogram of live weight gain showed a very significant differentiation among the three systems. The FEE for group G was $\$ 0.60 \pm 0.20 \mathrm{~kg}^{-1}$ LW gain; for group GC, $\$ 1.25 \pm 0.19 \mathrm{~kg}^{-1} \mathrm{LW}$ gain; and for group C it was $\$ 1.89 \pm 0.16 \mathrm{~kg}^{-1} \mathrm{LW}$ gain (Table 1).

Lambs from groups $\mathrm{G}$ and $\mathrm{GC}$ gave the highest value for dressing percentage: $46.24 \pm 1.42 \%$ and $46.17 \pm 1.53 \%$, respectively (Table 2). Differences in pre- and postslaughter characteristics among G, GC, and C lambs were generally not significant. Drip loss (DL) was, however, significant among the three groups and the highest was found in GC group. Slaughter weight (SW) was highest in $\mathrm{C}$ group and significant generally on $\mathrm{HCW}(\mathrm{P}<0.001)$, CCW $(\mathrm{P}<0.001)$, and DL $(\mathrm{P}<0.05)$.

Significant differences $(\mathrm{P}<0.01)$ in $\mathrm{BF}, \mathrm{MD}, \mathrm{MW}$, and MA were detected among the three varying feeding protocols. The MLD values were lowest in the G group and highest in the $\mathrm{C}$ group of lambs (Table 3). With carcass characteristics, the different feeding regimes seemed to only significantly affect the rib percentage $(\mathrm{P}<0.01)$; no significant differences were found among long leg, shoulder, neck, and flank. The regression coefficients of cold carcass weight on rib and flank were significant $(\mathrm{P}<0.05)$. No significant difference was detected on the longissimus dorsi muscle for colour measurement values $\left(\mathrm{L}^{*}, \mathrm{a}^{*}\right.$, and $\left.\mathrm{b}^{*}\right)$. Variations in $\mathrm{pH}$ were also insignificant among the three feeding regimes (Table 4). A significant positive correlation was determined between $\mathrm{SW}$ and $\mathrm{CCW}$ $(\mathrm{r}=0.906 ; \mathrm{P}<0.001), \mathrm{BF}$ and $\mathrm{MW}(\mathrm{r}=0.658 ; \mathrm{P}<0.01)$, $\mathrm{MA}$ and $\mathrm{BF}(\mathrm{r}=0.754 ; \mathrm{P}<0.01)$, MA and $\mathrm{MM}(\mathrm{r}=0.808$; $\mathrm{P}<0.001)$, and MA and MD $(\mathrm{r}=0.595 ; \mathrm{P}<0.01)$ (Table 5).

The variation, which is considered as fixed factors between different feeding regimes, showed that $\mathrm{SF}$ $(\mathrm{P}<0.01), \quad \mathrm{CL} \quad(\mathrm{P}<0.001)$, and $\mathrm{WL} \quad(\mathrm{P}<0.001)$ were significant (Table 6). The shear force values in all groups were found to be within acceptable levels. The G Group had the highest shear force, $3.55 \pm 0.25 \mathrm{~kg} / \mathrm{cm}^{2}$, while the lowest shear force was observed in the $\mathrm{C}$ group $(1.94 \pm 0.25$ $\left.\mathrm{kg} / \mathrm{cm}^{2}\right)$. The G Group carcass experienced more than twice the water loss $(4.12 \pm 0.17 \%)$ compared with the other two groups (C group: $1.61 \pm 0.17 \%$, and GC group: $2.00 \pm 0.17 \%$ ), as well as approximately $20 \%$ greater cooking loss $(35.75 \pm 0.77 \%)$ in relation to groups GC $(31.44 \pm 0.77 \%)$

Table 1 - Least square means and standard errors of ADG, feed intake, and cost per kilogram of live weight gain under different feeding protocols

\begin{tabular}{|c|c|c|c|c|c|c|c|}
\hline Feeding protocol & $\mathrm{N}$ & IW (kg) & ADG (g/day) & TWG (kg) & $\begin{array}{c}\text { ADFI } \\
\text { (Total DM-g/d/head) }\end{array}$ & Feed cost $(\mathrm{US} \$ / \mathrm{d})$ & FEE (US\$/kg) ${ }^{1}$ \\
\hline & & $\mathrm{P}=0.857$ & $\mathrm{P}=0.028$ & $\mathrm{P}=0.042$ & $\mathrm{P}=0.040$ & $\mathrm{P}=0.000$ & $\mathrm{P}=0.000$ \\
\hline G & 15 & $22.70 \pm 1.70$ & $115.87 \pm 11.91 \mathrm{a}$ & $8.38 \pm 1.21 \mathrm{a}$ & $740.21 \pm 12.22 \mathrm{a}$ & $0.07 \pm 0.003$ & $0.60 \pm 0.20 \mathrm{a}$ \\
\hline $\mathrm{C}$ & 15 & $21.80 \pm 1.70$ & $161.40 \pm 9.71 b$ & $13.28 \pm 1.71 \mathrm{~b}$ & $698.48 \pm 9.96 \mathrm{a}$ & $0.30 \pm 0.017$ & $1.89 \pm 0.16 \mathrm{~b}$ \\
\hline Linear regression & & & $\mathrm{P}=0.050$ & $\mathrm{P}=0.050$ & $\mathrm{P}=0.000$ & $\mathrm{P}=0.000$ & $\mathrm{P}=0.200$ \\
\hline Slaughter weight & & & $2.062 \pm 1.01$ & $2.062 \pm 1.01$ & $6.769 \pm 1.04$ & $6.769 \pm 1.04$ & $-0.022 \pm 0.02$ \\
\hline
\end{tabular}

G - grazing; GC - grazing + concentrate; C - concentrate + alfalfa hay; N - number of animals; IW - initial weight; ADG - average daily gain; TWG - total weight gain; ADFI - average daily feed intake; DM - dry matter; FEE - feed expense efficiency.

${ }^{1}$ (US\$ $\mathrm{kg}^{-1}$ of live weight gain).

$\mathrm{a}, \mathrm{b}$ - letters indicate significance.

Table 2 - Least square means and standard errors of carcass characteristics under different feeding protocols

\begin{tabular}{lcccccc}
\hline Factor & $\mathrm{N}$ & $\mathrm{HCW}(\mathrm{kg})$ & $\mathrm{CCW}(\mathrm{kg})$ & $\mathrm{DP}(\%)$ & $\mathrm{DL}(\%)$ & $\mathrm{SW}(\mathrm{kg})$ \\
\hline Production system & & $\mathrm{P}=0.635$ & $\mathrm{P}=0.657$ & $\mathrm{P}=0.777$ & $\mathrm{P}=0.044$ & $\mathrm{P}=0.095$ \\
$\mathrm{G}$ & 15 & $15.17 \pm 0.44$ & $14.96 \pm 0.44$ & $46.24 \pm 1.42$ & $1.38 \pm 0.04$ & $30.31 \pm 1.16$ \\
$\mathrm{GC}$ & 15 & $15.31 \pm 0.48$ & $15.08 \pm 0.47$ & $46.17 \pm 1.53$ & $1.48 \pm 0.04$ & $32.10 \pm 1.16$ \\
$\mathrm{C}$ & 15 & $14.7 \pm 0.44$ & $14.51 \pm 0.44$ & $44.9 \pm 1.43$ & $1.31 \pm 0.04$ & $34.28 \pm 1.15$ \\
Linear regression & & $\mathrm{P}=0.000$ & $\mathrm{P}=0.000$ & $\mathrm{P}=0.981$ & $\mathrm{P}=0.081$ & $22.70 \pm 1.70$ \\
Slaughter weight & & $0.490 \pm 0.07$ & $0.485 \pm 0.07$ & $0.006 \pm 0.24$ & $-0.013 \pm 0.01$ & $\mathrm{P}=0.002$ \\
Linear regression & & & & & $0.764 \pm 0.19$ \\
Initial weight & & & & & $32.82 \pm 0.70$ \\
Total & 45 & $15.06 \pm 0.26$ & $14.85 \pm 0.25$ & $45.77 \pm 0.82$ & $1.39 \pm 0.02$ & $22.10 \pm 1.70$ \\
\hline
\end{tabular}

G - grazing; GC - grazing + concentrate; C - concentrate + alfalfa hay; IW - initial weight; N - number of animals; HCW - hot carcass weight; CCW - cold carcass weight; DP - dressing percentage; DL - drip loss; SW - slaughter weight. 
Table 3 - Least square means and standard errors of the longissimus dorsi muscle and carcass components

\begin{tabular}{|c|c|c|c|c|c|c|c|c|c|c|}
\hline Factor & $\mathrm{N}$ & $\mathrm{BF}(\mathrm{cm})$ & $\mathrm{MD}(\mathrm{cm})$ & $\mathrm{MW}(\mathrm{cm})$ & $\mathrm{MA}\left(\mathrm{cm}^{2}\right)$ & Long leg $(\%)$ & Shoulder (\%) & Neck (\%) & Rib (\%) & Flank (\%) \\
\hline Production system & & $\mathrm{P}=0.005$ & $\mathrm{P}=0.003$ & $\mathrm{P}=0.002$ & $\mathrm{P}=0.000$ & $\mathrm{P}=0.051$ & $\mathrm{P}=0.098$ & $P=0.590$ & $\mathrm{P}=0.004$ & $\mathrm{P}=0.093$ \\
\hline G & 15 & $0.16 \pm 0.03$ & $3.71 \pm 0.20$ & $4.83 \pm 0.14$ & $14.48 \pm 0.96$ & $47.61 \pm 0.71$ & $19.42 \pm 0.59$ & $8.57 \pm 0.29$ & $19.46 \pm 0.48$ & $6.33 \pm 0.36$ \\
\hline GC & 15 & $0.23 \pm 0.03$ & $4.19 \pm 0.19$ & $5.23 \pm 0.13$ & $18.10 \pm 0.95$ & $44.84 \pm 0.69$ & $20.38 \pm 0.58$ & $8.76 \pm 0.29$ & $20.04 \pm 0.47$ & $7.50 \pm 0.35$ \\
\hline LR & & $\mathrm{P}=0.956$ & $\mathrm{P}=0.494$ & $\mathrm{P}=0.849$ & $\mathrm{P}=0.932$ & $\mathrm{P}=0.132$ & $\mathrm{P}=0.134$ & $\mathrm{P}=0.823$ & $\mathrm{P}=0.028$ & $\mathrm{P}=0.033$ \\
\hline $\mathrm{CCW}$ & & $-0.001 \pm 0.01$ & $0.044 \pm 0.06$ & $0.008 \pm 0.04$ & $-0.026 \pm 0.29$ & $-0.356 \pm 0.22$ & $-0.294 \pm 0.18$ & $-0.021 \pm 0.09$ & $0.376 \pm 0.15$ & $0.27 \pm 0.11$ \\
\hline Total & 45 & $0.25 \pm 0.02$ & $4.30 \pm 0.11$ & $5.28 \pm 0.08$ & $18.43 \pm 0.55$ & $46.27 \pm 0.40$ & $20.42 \pm 0.33$ & $8.78 \pm 0.16$ & $18.91 \pm 0.27$ & $7.03 \pm 0.20$ \\
\hline
\end{tabular}

G - grazing; GC - grazing + concentrate; C - concentrate + alfalfa hay; LR - linear regression; CCW - cold carcass weight (kg); N - number of animals; BF - backfat thickness MD - muscle depth; MW - muscle width; MA - muscle area.

Table 4 - Least square means and standard errors of $\mathrm{pH}$ and color characteristics

\begin{tabular}{lcccccc}
\hline Factor & $\mathrm{N}$ & $\mathrm{pH}_{45}$ & $\mathrm{pH}_{24}$ & $\mathrm{~L}^{*}$ & $\mathrm{a}^{*}$ & $\mathrm{~b}$ \\
\hline Production system & & $\mathrm{P}=0.09$ & $\mathrm{P}=0.936$ & $\mathrm{P}=0.822$ & $\mathrm{P}=0.632$ & $\mathrm{P}=0.724$ \\
$\mathrm{G}$ & 15 & $6.10 \pm 0.04$ & $5.76 \pm 0.05$ & $39.70 \pm 1.69$ & $12.25 \pm 0.88$ & $12.91 \pm 0.54$ \\
$\mathrm{GC}$ & 15 & $6.15 \pm 0.04$ & $5.75 \pm 0.05$ & $40.40 \pm 1.69$ & $12.58 \pm 0.88$ & $13.21 \pm 0.54$ \\
$\mathrm{C}$ & 15 & $6.23 \pm 0.04$ & $5.77 \pm 0.05$ & $41.21 \pm 1.69$ & $11.41 \pm 0.88$ & $12.59 \pm 0.54$ \\
Total & 45 & $6.16 \pm 0.02$ & $5.76 \pm 0.03$ & $40.44 \pm 0.97$ & $12.08 \pm 0.51$ & $12.9 \pm 0.31$ \\
\hline
\end{tabular}

$\mathrm{G}$ - grazing; GC - grazing + concentrate; $\mathrm{C}$ - concentrate + alfalfa hay; $\mathrm{N}$ - number of animals; $\mathrm{pH}_{45}$ - $\mathrm{pH} 45$ min after slaughter; $\mathrm{pH}_{24}$ - $\mathrm{pH} 24$ h after slaughter; $\mathrm{L}^{*}$ - lightness; $a^{*}$ - redness; $b^{*}$ - yellowness.

and $\mathrm{C}(28.83 \pm 0.77 \%)$. All the phenotypic correlations were highly significant $(\mathrm{P}<0.01, \mathrm{P}<0.001)$ (Table 7). The highest correlation coefficient was found between cooking loss and water loss values. When looking at correlation coefficients between meat instrumental data and slaughter weight (Table 8), there was a positive correlation between SW and $\mathrm{a}^{*}(\mathrm{r}=0.653 ; \mathrm{P}<0.01)$ and a negative correlation between lightness $\left(\mathrm{L}^{*}\right)$ and $\mathrm{SW}(\mathrm{r}=-0.548 ; \mathrm{P}<0.05)$ and redness $\left(\mathrm{a}^{*}\right)$ and lightness $\left(\mathrm{L}^{*}\right)(\mathrm{r}=-0.670 ; \mathrm{P}<0.01)$.

Table 5 - Phenotypic correlation coefficients among carcass and meat measurements

\begin{tabular}{lccccc}
\hline & $\mathrm{SW}(\mathrm{kg})$ & $\mathrm{CCW}(\mathrm{kg})$ & $\mathrm{BF}(\mathrm{cm})$ & $\mathrm{MD}(\mathrm{cm})$ & $\mathrm{MW}(\mathrm{cm})$ \\
\hline $\mathrm{CCW}(\mathrm{kg})$ & $0.906^{* * *}$ & & & & \\
$\mathrm{BF}(\mathrm{cm})$ & $0.260 \mathrm{NS}$ & $0.188 \mathrm{NS}$ & & & \\
$\mathrm{MD}(\mathrm{cm})$ & $0.485 \mathrm{NS}$ & $0.319 \mathrm{NS}$ & $0.468 \mathrm{NS}$ & & \\
$\mathrm{MW}(\mathrm{cm})$ & $0.349 \mathrm{NS}$ & $0.238 \mathrm{NS}$ & $0.658^{* *}$ & $0.812^{* * *}$ & \\
MA $\left(\mathrm{cm}^{2}\right)$ & $0.337 \mathrm{NS}$ & $0.205 \mathrm{NS}$ & $0.754^{* *}$ & $0.595^{* *}$ & $0.808^{* * *}$ \\
\hline
\end{tabular}

SW - slaughter weight; CCW - cold carcass weight; BF - backfat thickness; MD muscle depth; MW - muscle width; MA - muscle area.

$* \mathrm{P}<0.05 ; * * \mathrm{P}<0.01 ; * * * \mathrm{P}<0.001 ; \mathrm{NS}$ - not significant.

Table 6 - Least square means and standard errors of meat characteristics

\begin{tabular}{lcccc}
\hline Factor & $\mathrm{N}$ & $\begin{array}{c}\text { Shear force } \\
\left(\mathrm{kg} / \mathrm{cm}^{2}\right)\end{array}$ & $\begin{array}{c}\text { Cooking loss } \\
(\%)\end{array}$ & $\begin{array}{c}\text { Water loss } \\
(\%)\end{array}$ \\
\hline Production system & & $\mathrm{P}=0.002$ & $\mathrm{P}=0.000$ & $\mathrm{P}=0.000$ \\
G & 15 & $3.55 \pm 0.25$ & $35.75 \pm 0.77$ & $4.12 \pm 0.17$ \\
GC & 15 & $2.48 \pm 0.25$ & $31.44 \pm 0.77$ & $2.00 \pm 0.17$ \\
C & 15 & $1.94 \pm 0.25$ & $28.83 \pm 0.77$ & $1.61 \pm 0.17$ \\
Total & 45 & $2.65 \pm 0.14$ & $32.01 \pm 0.44$ & $2.57 \pm 0.10$ \\
\hline
\end{tabular}

G - grazing; GC - grazing + concentrate; C - concentrate + alfalfa hay; $\mathrm{N}$ - number of animals.
Table 7 - Phenotypic correlation coefficients among water loss, cooking loss, and shear force

\begin{tabular}{lcc}
\hline & Shear force $(\mathrm{kg})$ & Cooking loss $(\%)$ \\
\hline Cooking loss $(\%)$ & $0.768^{* *}$ & \\
Water loss $(\%)$ & $0.661^{* *}$ & $0.792^{* * *}$ \\
\hline
\end{tabular}

$* * \mathrm{P}=0.01 ; * * * \mathrm{P}<0.001$.

Table 8 - Correlation coefficients among meat instrumental data and slaughter weight

\begin{tabular}{|c|c|c|c|c|c|}
\hline & $\mathrm{SW}(\mathrm{kg})$ & $\mathrm{pH}_{45}$ & $\mathrm{pH}_{24}$ & $\mathrm{~L}^{*}$ & $a^{*}$ \\
\hline $\mathrm{pH}_{45}$ & $-0.043 \mathrm{NS}$ & & & & \\
\hline $\mathrm{pH}_{24}$ & $0.084 \mathrm{NS}$ & $-0.076 \mathrm{NS}$ & & & \\
\hline $\mathrm{L}^{*}$ & $-0.509^{*}$ & $-0.120 \mathrm{NS}$ & $-0.194 \mathrm{NS}$ & & \\
\hline$a^{*}$ & $0.633 * *$ & $-0.427 \mathrm{NS}$ & $0.262 \mathrm{NS}$ & $-0.670 * *$ & \\
\hline$b^{*}$ & $0.084 \mathrm{NS}$ & $-0.558^{*}$ & $0.138 \mathrm{NS}$ & $0.313 \mathrm{NS}$ & $0.375 \mathrm{NS}$ \\
\hline
\end{tabular}

$\mathrm{SW}$ - slaughter weight; $\mathrm{pH}_{45}$ - $\mathrm{pH} 45$ min after slaughter; $\mathrm{pH}_{24}$ - $\mathrm{pH} 24 \mathrm{~h}$ after slaughter; $\mathrm{L}^{*}$ - lightness; $\mathrm{a}^{*}$ - redness; $\mathrm{b}^{*}$ - yellowness.

${ }^{*} \mathrm{P}<0.05 ; * * \mathrm{P}<0.01 ; \mathrm{NS}$ - not significant.

\section{Discussion}

During the 62-day experiment period, the statistically significant difference in growth was attributed to the three different feeding protocols. Average daily weight gain (ADG) was the lowest in pasture-raised (G) lambs $\left(115.87 \pm 11.91 \mathrm{~g} \mathrm{day}^{-1}\right)$, followed by the GC group $\left(142.88 \pm 11.49 \mathrm{~g}\right.$ day $\left.^{-1}\right)$ with the highest ADG attributed to the feedlot concentrate (C) group at $161.40 \pm 9.71 \mathrm{~g}^{\mathrm{day}^{-1}}$. These were much lower than figures reported by Yeaman et al. (2014), more than likely due to the ad libitum concentrate feeding regime used in that study, but were similar to 
findings of Cañeque et al. (1990) and Diaz et al. (2002), also on restricted feeding. Additionally, the low ADG for the grass fed $(\mathrm{G})$ group may also have been attributable to the limited quality of the pasture for the region during the dry summer experiment period. The study looked at the cost efficiencies in the differing feed regimes. Whilst it was relatively simple to calculate the feed intake and thus the cost of the $\mathrm{C}$ Group, a number of assumptions needed to be made with the $\mathrm{G}$ and the $\mathrm{GC}$ groups, as it is always a major challenge to estimate the grazing intake of a sheep. Intake of grazing ruminants can be estimated basically through two methods: direct or indirect. Indirect methods include the marker techniques, ratio techniques, the recording of animal behaviour, and other empirical models. This study chose to estimate the grazing feed intake by direct measurement of herbage mass as per Macoon et al. (2003) and Smit et al. (2005), in which the herbage mass was recorded before and after grazing. The mass was estimated by cutting and weighing the grass harvested on a defined area then drying to ascertain the DM content. We chose to keep the stocking rate relatively high, at 1.8 DSE (dry sheep equivalent), ideally to graze and consume the majority of the grass as per the designated area. The grazing period was linked to the grass re-growth during that period, in order to minimize the error of estimation. Rather than using enclosure cages, the study used electric fencing to guide the lambs. Indeed, even if, according to the definition of Baumont et al. (2000) "intake is the maximum quantity of feed that can be eaten by an animal when this is supplied ad libitum as the sole feed", whilst seemingly easy to quantify, its study is more complex. Plant properties, associated for example with the presence of toxins, the taste or smell, are important parameters impacting diet selection and feeding behavior of grazing ruminants and so the intake level (Provenza et al., 2003). A huge intake level variability also occurs between breed or individuals within a given breed (Scott and Provenza, 1999; Pearson et al., 2005). As an example, Dorper sheep are less selective grazers, consume more shrubs and bushes and ingest a larger number of different plant species than Merino sheep (Brand, 2000). Equally complex to voluntary intake is also the estimation with sufficient precision of in vivo digestibility. To estimate more rapidly and easily the in vivo digestibility, different alternative methods exist and are well documented. Some of them are based on regressions between in vivo digestibility and forage characteristics such as cellulose (Lecomte et al., 1992), plant morphological characteristics (Demarquilly and Jarrige, 1981), or plant physiological stage (Valente et al., 2000). If these methods are sufficiently accurate to estimate the in vivo digestibility of pure grass sward, they are less appropriate for mixed forages due to the presence of various plant species differing in terms of chemical composition or morphological development stage. According to various French references, in grazing, the ad libitum intake of a reference grass (15\% crude protein, $77 \%$ organic matter digestibility, on a dry matter basis) is $75 \mathrm{~g}$ of dry matter per $\mathrm{kg}$ of metabolic weight for a standard sheep. On this basis, it is possible to calculate the "fill unit" of various forages (INRA, 2007). The authors utilized the above data in estimating the final feed intake figures for the $\mathrm{G}$ and the GC groups and thus allowing the calculation the cost of feed from grazing (Table 1).

As seen in the results, despite ADG being higher for the $\mathrm{C}$ group, the cost of feed to attain the same live weight gain was much higher than for the $G$ group. Sheep producers often aim to reduce the feed costs by finding suitable breeds that efficiently convert pasture to meat. This was part of the reason for introducing the Dorper breed for this experimentation. In many of the efficient meat-producing countries around the world, the Dorper breed has yielded the most productive conversion rates. For lambs, the feed conversion ratio (FCR - kg feed dry matter intake per kg live mass gain) is often in the range of about 4 to 5 on high-concentrate diets (Brand et al., 1991; Knott et al., 2003; NRC, 2007), 5 to 6 on some forages of good quality (Fahmy et al., 1992), and more than 6 on feeds of lesser quality (Malik et al., 1996). In the feedlot situation, the Dorper has an excellent feed conversion ratio of $4 \mathrm{~kg}$ of feed to $1 \mathrm{~kg}$ of growth, a $20 \%$ increase in feed conversion when compared with other crossbreeds. With increasing global demand for grains influencing higher grain prices, this is clearly a major production advantage. The conversion ratio in this study comparatively was $4.3: 1$ for the C group, 4.7:1 for the GC group, and 6.4:1 for the $\mathrm{G}$ group. The total average concentrate pellet consumption per lamb over the 62 day experimental period for the GC and the $\mathrm{C}$ groups was $24.6 \mathrm{~kg}$ and $41.0 \mathrm{~kg}$, respectively (i.e., $300 \mathrm{~g} \mathrm{day}^{-1}$ and $500 \mathrm{~g}$ day $^{-1}$, respectively). While the $\mathrm{GC}$ group attained its roughage needs from grazing, the $\mathrm{C}$ group was provided alfalfa hay at an average of $32 \mathrm{~kg} \mathrm{lamb}^{-1}$ during the experiment period.

The new measurement index used in the study titled feed expense efficiency (FEE) showed the actual cost of feed for each $\mathrm{kg}$ of live weight gained by the lamb proved to be a valuable tool to correctly ascertain the productivity of the production system. The FEE for group C was $\$ 1.89$; for the grazing plus concentrate fed animals (GC group), FEE was $\$ 1.25$; and only $\$ 0.60$ for the pasture-grazing lambs (G group) (Table 1), thereby making the $\mathrm{G}$ group $310 \%$ more productive then the $\mathrm{C}$ group, and $200 \%$ more 
productive than the GC group. Feed cost being the main determining factor for the economic sustainability of most livestock operations, the study showed that understanding which component of the lamb fattening process affects the profitability is the key to the success of operations. In Turkey, large-scale units have mainly relied on intensive feedlot-type production systems which use water-inefficient and expensive cereals, silage, lucerne hay, and concentrates as their main fodder as opposed to the more traditional native pasture-grazing as the primary feed during the growing season. As Dorpers are non-selective grazers, this enables them to run on the same amount of land and utilise a wider variety of feed resources as compared with other conventional breeds. This characteristic would also assist the Turkish farmer with a more sustainable pasture management program.

The carcass fat content for all the experimental lambs was very low. Based on numerous past publications, the authors felt that the low fat values in all three groups must have been a specific trait of the Dorper breed. Carcasses of similar-age lambs of other local breeds in the abattoir all had significantly higher visual fat. Backfat (BF), albeit fairly minimal, was highest in $\mathrm{C}$ lambs, which was an expected result due to grazing $(\mathrm{G})$ lambs generally producing less fat than concentrate-fed (C) lambs (Murphy et al., 1994; Diaz et al., 2002). This is possibly due to changes in the metabolism of lambs at pasture caused by exercise (Diaz et al., 2002). Carcass fat content is an important feature in the Turkish lamb production sector, where the majority of producers often complain about the unproductive wasted tail and subcutaneous fat produced by the local breeds. The main types of sheep used in lamb production in Turkey are fat tailed breeds, yet the consumer preference for lamb meat particularly in the western region of the country is for a lean carcass. Dressing percentage was 3\% higher in the GC group lambs, in agreement with Santos-Silva et al. (2002) and Diaz et al. (2002). Similarly, an increase in the effect of dressing percentage on slaughter weight was also in agreement with Solomon et al. (1980), Kemp et al. (1981), Wood et al. (1983), Hawkins et al. (1985), Vergara et al. (1999), and Diaz et al. (2002). Of particular interest would be to know why the rib percentage was low in the grain-fed group. This may have been due to greater exercise required for the grazing process and, as such, the grass-fed lambs may have had a larger lung capacity, resulting in the higher rib percentage in the carcass.

Muscle traits (BF, MD, MW, and MA) were significant in all the varying feeding regimes and most developed for lambs reared solely on concentrates ( $\mathrm{C}$ group), probably as a consequence of higher energy content of the diet in this treatment. This finding was also supported by findings of Santos-Silva et al. (2002). However, all things considered, the authors felt that the minor muscle trait benefits seen in the $\mathrm{C}$ group to the undiscerning consumer do not justify the considerable additional production costs. This sentiment is shared by a number of farmers around the globe (Kintzel, 2010).

No significant differences were seen for instrumental muscle quality among the three feeding regimes. With regard to carcass colour, based on numerous earlier findings in GC, lightness $\left(L^{*}\right)$ is a parameter affected by feed (Vestergaard et al., 2000; Priolo et al., 2001; Diaz et al., 2002). Although the highest $L$ value in our study was obtained in group $\mathrm{C}$, indicating a lighter colour meat, it was insignificant by statistical standards. The colour of the meat has a great importance in the acceptance of meat by consumers in Turkey and, similarly to the EU Mediterranean countries (Santos-Silva et al., 2002), pale or pink red meat is preferred. The colour differences between lambs on different feeding regimes may be due to the different physical activity undertaken by the animals (Vestergaard et al., 2000). Lambs on pasture display a higher concentration of haemic pigments in the muscle (Renerre, 1986) than those on concentrate. Meat from grazing animals has often been associated with yellow fat (Priolo et al., 2001; Ripoll et al., 2008) and dark though a little flavoured (Priolo et al., 2002).

In this study, mean $\mathrm{pH}$ values ranged between 6.16 at $45 \mathrm{~min}$ post-mortem and 5.76 at $24 \mathrm{~h}$ post-mortem. These results were comparable to reports by Ekiz et al. (2009) and Sañudo et al. (2003) within the acceptable range as stated previously by Devine et al. (1993), Diaz et al. (2002), and Vergara et al. (1999). This also indicated that lambs were slaughtered under stress-free conditions; rigor mortis occurred appropriately, and slaughtering procedures were compatible within animal welfare standards. Slaughter weight was insignificant for $\mathrm{pH}$. Meat from $\mathrm{G}$ lambs with slightly higher SF values was tougher those from than GC and C lambs, agreeing with Yarali et al. (2014).

The Turkey market place does not pay a premium for higher quality meat; it has a fairly generic rate for meat, irrespective of the cut. Therefore, the study found that the considerable additional cost for feed to attain only marginal improvement in quality was a false investment.

There is an opportunity for Turkey to better utilize its water resources and become fodder self-sufficient with its lamb production systems by adopting irrigated pasture improvement for grazing as opposed to feedlotting, and introducing a breed like the Dorper to the equation with its ability to put grass into weight gain would make the industry far more sustainable. 


\section{Conclusions}

By using a more articulated calculation index, termed feed expense efficiency, the study concluded that pasture production provides a significant cost saving to the producer without compromising meat quality and is $300 \%$ more efficient in producing $1 \mathrm{~kg}$ of live weight then grainfed lambs. The Dorper breed produces very light fat on the carcass irrespective of the production system. For countries that are reliant on imported grains for fodder, the use of pasture-based feeds is encouraged as opposed to harvested feeds with conversion-efficient breeds such as Dorper sheep to improve productivity in the lamb meat industry.

\section{References}

Allison, C. D. 1985. Factors affecting forage intake by range ruminants. Journal of Range Management 38:305-311.

Baumont, R.; Prache, S.; Meuret, M. and Morhand Fehr, P. 2000. How forage characteristics influence behaviour and intake in small ruminants. Livestock Production Science 61:15-28.

Brand, T. S.; Cloete, S. W. P. and Franck, F. 1991. Wheat-straw as roughage component in finishing diets of growing lambs. South African Journal of Animal Science 21:184-188.

Brand, T. S. 2000. Grazing behaviour and diet selection by Dorper sheep. Small Ruminant Research 36:147-158.

Cañeque, V.; Huidobro, F.; Hernandez, J. A. and Dolz, J. F. 1990. Comparison between four fattening systems for lambs and their effects on carcass quality. p.180-181. In: Proceedings of the 41st Annual Meeting of the European Association for Animal Production. Toulouse, France.

Carpenter, Z. L. 1966. What is consumer-preffered lamb? Journal of Animal Science 24:1232-1235.

Chestnutt, D. M. B. 1994. Effect of lamb growth rate and growth pattern on carcass fat levels. Animal Production 58:77-85.

Cissé, M.; Lya, I.; Nianogo, A. J.; Sane, I.; Sawadogo, J. G.; N’Diaye, M.; Awad, C. and Fall, Y. 2002. Grazing behaviour and milk yield of sheep and goat. Small Ruminant Research 43:85-95.

Colomer-Rocher, F.; Morand-Fehr, P. and Kirton, A. H. 1987. Standard methods and procedures for goat carcass evaluation jointing and tissue separation. Livestock Production Science 17:149-157.

Demment, M. W. and Van Soest, P. J. 1985. A nutritional explanation for body-size patterns of ruminant and non-ruminant herbivores. American Naturalist 125:641-672.

Decruyenaere, V.; Buldgen, A. and Stilmant, D. 2009. Factors affecting intake by grazing ruminants and related quantification methods: Biotechnology, Agronomy, Society and Environment 13:559-573.

Demarquilly, C. and Jarrige, R. 1981. Panorama des méthodes de prévision de la digestibilité et de la valeur énergétique des fourrages. p.41-59. In: Prévision de la valeur nutritive des aliments des ruminants. INRA, Paris.

Devine, C. E.; Graafhuis, A. E.; Muir, P. D. and Chrystall, B. B. 1993. The effect of growth rate and ultimate $\mathrm{pH}$ on meat quality of lambs. Meat Science 35:63-77.

Diaz, M. T.; Velasco, S.; Caneque, V.; Lauzurica, S.; Ruiz de Huidobro, F.; Perez, C.; Gonzalez, J. and Manzanares, C. 2002. Use of concentrate or pasture for fattening lambs and its effect on carcass and meat quality. Small Ruminant Research 43:257-268.
Dicko, M. and Sikena, L. K. 1991. Feeding behaviour, quantitative and qualitative intake of browse by domestic ruminants. Animal Production and Health Paper 102, p.129-144. Available at: $<$ http://www.fao.org/livestock/agap/frg/ahpp102/102-129.pdf. $>$. Accessed on: Nov. 20, 2015.

Ekiz, B.; Yılmaz, A.; Ozcan, M.; Kaplan, C, Hanoglu, H.; Erdogan, I. and Yalcintan, H. 2009. Carcass measurements and meat quality of Turkish Merino, Ramlic, Kivircik, Chios and Imroz lambs raised under an extensive production system. Meat Science 82:64-70.

Fahmy, M. H.; Boucher, J. M.; Pose, L. M.; Grégoire, R.; Butler, G. and Comeau, J. E. 1992. Feed efficiency, carcass characteristics, and sensory quality of lambs, with or without prolific ancestry, fed diets with different protein supplements. Journal of Animal Science 70:1365-1374.

Guerin, H.; Friot, D.; Mbaye, N.; Richard, D. and Dieng, A. 1988. Diet of domestic ruminants (cattle, sheep, goats) exploiting Sahelian and Soudano-Sahelian natural pastures: II. Description of a test of diet through a behaviour study. Variation factors of diet selection and the nutritive consequences. Revue d'Élevage et de Médecine Vétérinaire des Pays Tropicaux 41:427-440.

Gursoy, O. 2006. Economics and profitability of sheep and goat production in Turkey under new support regimes and market conditions. Small Ruminant Research 62:181-191.

Hawkins, R. R.; Kemp, J. D.; Ely, D. G.; Fox, J. D.; Moody, W. G. and Vimini, R. J. 1985. Carcass and meat characteristics of crossbred lambs born to ewes of different genetic types and slaughtered at different weights. Livestock Production Science 12:241-250.

Hoffman, L. C.; Muller, M.; Cloete, S. W. P. and Schmidt, D. 2003. Comparison of six crossbred lamb types: Sensory, physical and nutritional meat quality characteristics. Meat Science 65:1265-1274.

INRA - L'Institut National de la Recherche Agronomique. 2007. Alimentation des bovins, ovins et caprins. Besoins des animaux, valeurs des aliments. Editions Quae, Versailles, France.

Joy, M.; Alvarez-Rodrigez, J.; Revilla, R.; Delfa, R. and Ripoll, G. 2008. Ewe metabolic performance and lambs carcass traits in pasture and concentrate base production systems in churra Tensina breed. Small Ruminant Research 75:24-35.

Kemp, J. D.; Ely, D. G.; Fox, J. D. and Moody, W. G. 1981. Carcass and meat characteristics of crossbred lambs with and without Finnish Landrace breeding. Journal of Animal Science 52:1026-1033.

Kintzel, U. 2010. Cornell University Small Farms Program website. Available at: <http://smallfarms.cornell.edu/2011/01/09/dorpersheep-truths-and-myths/>. Accessed on: Sept. 5, 2015.

Knott, S. A.; Leury, B. J.; Cummins, L. J.; Brien, F. D. and Dunshea, F. R. 2003. Relationship between body composition, net feed intake and gross feed conversion efficiency in composite sire line sheep. In: Souffrant, W. B. and Metges, C. C., eds. Progress in research on energy and protein metabolism. EAAP Publication, Wageningen.

Lecomte, P. H.; Dardenne, P. and Agneessens, R. 1992. Prédiction de la digestibilité de la matière organique des fourrages verts par la méthode enzymatique à la pepsine cellulase et par spectrométrie dans le proche infrarouge. Revista de Agricultura 45:77-81.

Macoon, B.; Sollenberger, L. E.; Moore, J. E.; Staples, C. R.; Fike, J. H. and Portier, K. M. 2003. Comparison of three techniques for estimating the forage intake of lactating dairy cows at pasture. Journal of Animal Science 81:2357-2366.

Malik, R. C.; Razzaque, M. A.; Abbas, S.; Al-Khozam, N. and Sahni, S. 1996. Feedlot growth and efficiency of three-way cross lambs as affected by genotype, age and diet. Proceedings of the Australian Society of Animal Production 21:251-254.

Meissner, H. H. and Paulsmeier, D. V. 1995. Plant compositional constituents affecting between-plant and animal species prediction of forage intake. Journal of Animal Science 73:2447-2457. 
Murphy, T. A.; Loerch, S. C.; McClure, K. E. and Solomon, M. B. 1994. Effects of restricted feeding on growth performance and carcass composition of lambs subjected to different nutritional treatments. Journal of Animal Science 72:3131-3137.

NRC - National Research Council. 2007. Nutrient requirements of small ruminants. National Academies Press, Washington, DC.

Ocak, S.; Torun, O. and Guney, O. 2007. A novel method of analyzing rearing system on lamb growth and farm profitability. African Journal of Agricultural Research 6:495-499.

Pulina, G.; Avondo, M.; Molle, G.; Francesconi, A. H. D.; Atzori, A. S. and Cannas, A. 2013. Models for estimating feed intake in small ruminants. Revista Brasileira de Zootecnia 42:675-690.

Pearson, R. A.; Archibald, R. F. and Muirhead, R. H. 2005. A comparison of the effect of forage type and level of feeding on the digestibility and gastrointestinal mean retention time of dry forages given to cattle, sheep, ponies and donkeys. British Journal of Nutrition 95:88-98.

Priolo, A.; Micol, D. and Agabriel, J. 2001. Effect of grass feeding systems on ruminant meat colour and flavor. Animal Research 50:185-200.

Priolo, A.; Micol, D.; Agabriel, J.; Prache, S. and Dransfield, E. 2002. Effect of grass or concentrate feeding systems on lamb carcass and meat quality. Meat Science 62:179-185.

Provenza, F. D. 2003. Foraging behavior: managing to survive in a world of change. Washington, DC.

Provenza, F. D.; Villalba, J. J.; Dziba, L. E.; Atwood, S. B. and Banner, R. E. 2003. Linking herbivore experience, varied diets, and plant biochemical diversity. Small Ruminant Research 49:257-274.

Renerre, M. 1986. Influence des facteurs biologiques et technologiques sur la couleur de la viande bovine. Bulletin Technical 65:41-45.

Ripoll, G.; Joy, M.; Munoz, F. and Alberti, P. 2008. Meat and fat colour as a tool to trace grass-feeding systems in light lamb production. Meat Science 80:239-248.

Sauvant, D.; Assoumaya, C.; Giger-Reverdin, S. and Archimède, H. 2006. Etude comparative du mode d'expression du niveau d'alimentation chez les ruminants. In: Actes des 13th Journées Autour des Recherches sur les Ruminants, Rencontres Recherches Ruminants. Paris, France. INRA Editions, 103.

Santos-Silva, J.; Mendes, I. A. and Bessa, R. J. B. 2002. The effect of genotype, feeding system and slaughter weight on the quality of light lambs. 1. Growth, carcass composition and meat quality. Livestock Production Science 76:17-25.

Sañudo, C.; Alfonso, M.; Sanchez, A.; Berge, P.; Dransfield, E. and Zygoyiannis, D. 2003. Meat texture of lambs from different European production systems. Australian Journal of Agricultural Research 54:551-560.

Schwartz, H. J. and Schafft, H. 1988. A review of potential and constraints arising from the biology of animals. p.24-38. In: Workshop. Serdang, Malaysia.

Scott, L. L. and Provenza, F. D. 1999. Variation in food selection among lambs: effects of basal diet and foods offered in a meal. Journal of Animal Science 77:2391-2397.

Smit, H. J.; Taweel, H. Z.; Tas, B. M. and Elgersma, A. 2005. Comparison of techniques for estimating herbage intake of grazing dairy cows. Journal of Dairy Science 88:1827-1836.

Solomon, M. B.; Kemp, J. D.; Moody, W. G.; Ely, D. G. and Fox, J. D. 1980. Effect of breed and slaughter weight on physical, chemical and organoleptic properties of lamb carcasses. Journal of Animal Science 51:1102-1107.

Valente, M. E.; Borreani, G.; Peiretti, P. G. and Tabacco, E. 2000. Codified morphological stage for predicting digestibility of Italian ryegrass during spring cycle. Agronomy Journal 92:967-973.

Vergara, H.; Molina, A. and Gallego, L. 1999. Influence of sex and slaughter weight on carcass and meat quality in light and medium weight lambs produced in intensive systems. Meat Science 52:221-226.

Vestergaard, M.; Oksbjerg, N. and Henckel, P. 2000. Influence of feeding intensity, grazing and finishing feeding on muscle fibre characteristics and meat colour of semitendinosus, longissimus dorsi and supraspinatus muscles of young bulls. Meat Science 54:177-185.

Wood, J. D.; MacFie, H. J. H. and Brown, A. J. 1983. Effects of body weight, breed and sex on killing-out percentage and non-carcass component weights in lambs. Meat Science 9:89-99.

Yarali, E.; Yılmaz, O.; Cemal, I.; Karaca, O. and Taşkın, T. 2014. Meat quality characteristics in Kıvırcık lambs. Turkish Journal of Veterinary and Animal Sciences 34:452-458.

Yeaman, J. C.; Waldron, D. E. and Willingham, T. D. 2014. Growth and feed conversion efficiency of Dorper and Rambouillet lambs. Journal of Animal Science 91:4628-4632. 